\title{
SPORTS IDOLS OF SENIOR ATHLETES
}

\author{
Jelena Ilić ${ }^{1}$ \\ ${ }^{1}$ Republic Institute of Sport, Belgrade, Serbia
}

\section{SUMMARY}

The aim of this paper is to identify idols of senior athletes. And based on the identification of idols some conclusions can be made with respect to the system of values some person. The sample included 318 Serbian professional senior athletes (183 male and 135 female), 18 to 40 years old. Respondents were engaged in 28 different sports, mostly volleyball, water polo, basketball, karate, bocca, savate, handball, kyokushin. The independent variables were gender and selected idol and dependent variables were sport, gender, actuality and origin of idol. Senior athletes for their sports idols, in most cases elect Roger Federer, Michael Jordan, Milorad Čavić. It turns out that the majority of male and female athletes are selected for their idol person that comes out of their sport, but also that there are some differences in the choice of idols and characteristics of idols in male and female athletes.

Key Words: idolization, Serbia, values.

\section{INTRODUCTION}

Sport is a social product and cultural phenomenon: it is an integral part of cultural heritage and a genuine sort of collective activity. It reveals a lot about the values and norms which are dominant, emergent and residual in cultures and subcultures of society. Unlike other heroes, those idols that have emerged from sports are popular not only because of superior athleticism or impressive statistics, but also because of inspiring stories and symbolic feats. They are self-made heroes which became popular by their results and efforts. The status of a sports hero is not something that can be inherited, nor bought. It must be earned. And the more difficult the way to stardom was, the brighter the star shines. Sports heroes are always seen as representatives of good values. These good values are something that has meaning for the whole society. So it is essential that sports heroes have a society, a country or a sports club, that they represent. This is also case in economically poor countries, where question of success, victory or defeat, of nation sports idol, team, or representation becomes a state question and all eyes are on them. If he/she/they win, it is a nation success and they are glorified by all: public, journalist, families, politicians and everyone wants to be close and/or connected with them on some way. Sports celebrities are more than entertainers; they are expected to uphold their culture's values and morals at all times (Jones \& Schumann, 2000).

That is the reason why high profile professional sports stars enjoy extended coverage in media and they influence in society generally. Such attitude tout professional athletes as role models through uplifting tales of triumph over adversity, the importance of a positive outlook, and the value of a virtuous character can have different implications. Sports icons are interviewed before, during and after broadcasted sporting events and used as special guests of commentators in broadcasting of sports events. Newspapers, internet sites and sports news cable channels report on professional athletes' contracts, legal issues, and personal successes. Different magazines, tabloids and newspapers in theirs articles offer intimate details about sports celebrities' lives and their private life. Ads with sport celebrity endorsers have become increasingly popular; relative to the preceding 35 years, print ads of this type proliferated during the 1990s (Ibid).

This is also case in Serbia, so as mixture of sports and politicians. In almost every sports club and national federation management exist some politician 
and, in turn, athletes and clubs are used as mascots or symbols whose role is to send a message to certain group of electors and represent some target group. Namely, famous athletes stand to affect the attitudes and behaviors of those who idolize them (Chung, 2003). Athletic idols are very important part of their champagne because of their power to send a message, especially to the younger voters.

An idol is someone whose talents, achievements, status, and/or physical appearance are appreciated and celebrated by fans (Yue \& Cheung, 2000). Idolatry, manifested in worshipping and modeling behaviors, peaks during adolescence (Raviv, Bar-Tal, Raviv, $\&$ Ben-Horin, 1996). Worshipping may be expressed by collecting idol-related memorabilia or trying to meet the idol (Dubner, 2003); modeling is the effort to emulate an idol by mimicking his or her appearance, speech, and activities (Raviv et al., 1996).

De Ruyter and Conroy (2002) argue that the internalization is a dual process. An ideal becomes part of a person's ideal identity because she desires to be like an ideal person or to poses an ideal character trait. This involves not only a cognitive assessments, the person also deeply desires to become a certain person. Once it is part of her ideal identity, the ideal itself motivates her to strive towards its realization and act accordingly. This is the case when a person believes she is able to influence herself in the direction of her ideals and mean of person can reach it is an idolization, ie. choice of sports idol.

Symbolic benefits are referred to the identification (Maddux \& Rogers, 1980) and internalization (Kamins, Brand, Hoeke, \& Moe, 1989) experienced by the sport consumer in relation to the sport idol. Identification occurs when the sport consumer perceives the sport celebrity brand image as being attractive (Ibid), and is the "orientation of the self in regard to other objects including a person or group that results in feelings or sentiments of close attachments" (Maddux \& Rogers, 1980). Internalization has been described as taking place when an individual embraces the attitudes and behaviors of other individuals because of conformity in the values of the individuals (Premeaux, 2005). The appeal of sport stars is believed to be far more than just inspirational. Sport celebrities are believed to impact the lives of others to such a degree that they can shape the values and behaviors of those that admire them (Wann, Melnick, Russell, \& Pease, 2001). The attractiveness of the celebrity relies on the similarity, familiarity and liking of that celebrity by consumers (Erdogan 1999; Erdogan, Baker, \& Tagg, 2001; Maddux \& Rogers, 1980; McGuire, 1985). Adolescents view sport celebrities as the most heroic celebrities and that is why appealing athletic skills, pro-social behaviors, and traits of a star player can contribute to adolescents' identity construction (Stevens, Lathrop, \& Bradish, 2003) and later as adults, they idolize sport celebrities more intensely than other celebrities (McCutcheon, Lange, \& Houran, 2002).

So, at a very obvious level, it is reasonable to suppose that some sports stars inspire young players, since the phenomenon of idolization is a characteristic of adolescence. An idol is someone whose talents, achievements, status, or physical appearance are especially recognized and appreciated by his or her fans. Watching success and social status and wealth of senior athletes, young people, and especially young athletes, at the beginning of their career can be dazzled by them and that may have an influence on their choice of sport and decisions about their sport career and also their inner, adopted values. But also, as times goes by, with many years spend in sport, and with certain experience, winning and losing, athlete opinion about certain sports success and personality of top athletes and their personality inevitably changes.

Perhaps more famous for their celebrity status than for their greatness or heroism (Boorstin, 1961), professional athletes qua athletes are immortalized by their fans and have substantial influence on young admirers (Jones \& Schumann, 2000). Although sports heroes are recognized for their athletic greatness and sports celebrities are recognized for their fame (Stevens et al., 2003), characterizations such as idol, role model, and star are used synonymously (Bush, Martin, \& Bush, 2004; Lines, 2001). Young fans' reactions to a favorite celebrity may be called adoration, infatuation, and idolatry (Raviv et al., 1996); for athletes, such reactions may be sport dependent (Martin, 1996). Notwithstanding Charles Barkley's well-known protestations, sports role models can shape young admirers' attitudes and behaviors. For example, adolescents' demeanor, fashion, language, and mindset may all be influenced by the analogous traits of favored sports celebrities (Lines, 2001).

Sports heroes play a central role in the nationbuilding process, and in the creation of the national image, but in they are also used in image making and for the promotion of international corporations. These heroes can present a healing choice in hard times or times of national crisis. A sports hero can also function as a symbol of time. Sports heroes can symbolize economic growth. Or they can act as symbols of the process of internationalization of the whole society.

Role models, heroes and idols are a part of everyday life and therefore are thought to have a significant 
impact on the beliefs and actions of individuals. They are also frequently used in programs to deliver messages to a target group in order to evoke behaviour change. Research about athletic role models more commonly examines the influence of personally known role models, such as parents, peers, and coaches. As such, little is known about how and why famous or professional athletes are chosen and what influence they have on the athletes who admire them (Harris, 1986). The present study sought to contribute to the literature by addressing several unanswered questions about the prevalence, gender and some other characteristics of sports idols, particularly in domain of sport as profession. And especially uninvestigated area is examining of sports idols among athletes.

\section{METHODS}

The sample included 318 Serbian proffesional senior athletes (183 man and 135 woman), 18 to 40 years old $(M=21 ; S D=3.5)$. Respondents were engaged in 28 different sports (mostly volleyball, water polo, basketball, karate, bocca, savate, handball, kyokushin) and with significant sports' experience $(M=11, S D=4)$.

The independent variables were gender and selected idol and dependent variables were sport, gender, actuality (actual or retrieved) and origin (domestic or foreign) of an idol.

The instrument was constructed specially for this purpose and consisted of demographic data and open question about respondents' idol.

Data were analysed by chi-square and frequencies.

\section{TABLE 1}

List of sports idols of senior atbletes.

\begin{tabular}{clrlclc}
\hline \multirow{2}{*}{ Rank } & \multicolumn{2}{c}{ Total } & \multicolumn{3}{c}{ Male } & \multicolumn{2}{c}{ Female } \\
\cline { 2 - 7 } & \multicolumn{1}{c}{ Athlete } & $\%$ & \multicolumn{1}{c}{ Athlete } & $\%$ & Athlete & $\%$ \\
\hline 1 & Roger Federer & 8.5 & Michael Jordan & 19.0 & Roger Federer & 11.0 \\
\hline 2 & Michael Jordan & 8.2 & Milorad Čavić & 16.0 & Novak Đoković & 9.0 \\
\hline 3 & Milorad Čavić & 7.5 & Roger Federer & 16.0 & Milorad Čavić & 8.0 \\
\hline 4 & Usein Bolt & 6.0 & Usein Bolt & 11.0 & Usein Bolt & 8.0 \\
\hline 5 & Novak Đoković & 5.0 & Novak Đoković & 7.0 & Andrea Lekić & 7.0 \\
\hline 6 & Rafael Nadal & 3.5 & Rafael Nadal & 6.0 & Michael Jordan & 7.0 \\
\hline 7 & Andrea Lekić & 2.2 & Michael Felps & 5.0 & Jasna Šekarić & 5.0 \\
\hline 8 & Vladimir Vujasinović & 2.2 & Aleksandr Karelin & 4.0 & Rafael Nadal & 5.0 \\
\hline 9 & Jasna Šekarić & 1.9 & Vladimir Vujasinović & 4.0 & Jelena Janković & 4.0 \\
\hline
\end{tabular}

FIGURE 1

List of sports idols of senior athletes.

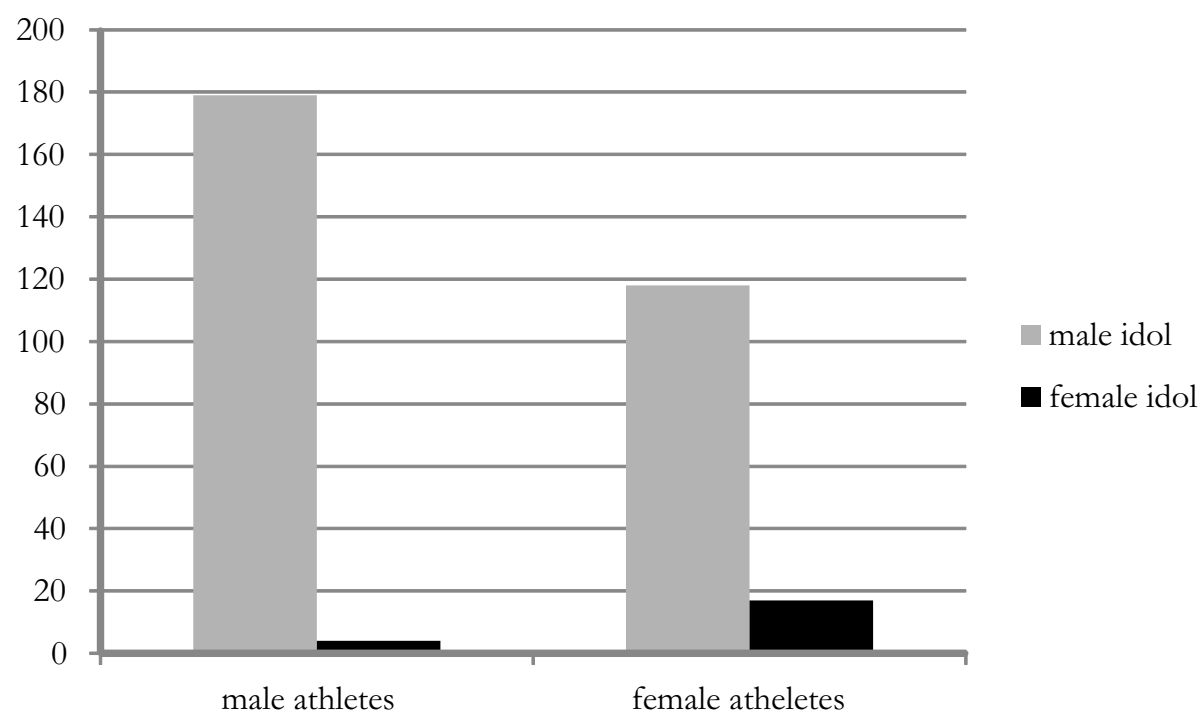




\section{RESULTS}

Senior athletes for their sports idols, in most cases elect Roger Federer, followed by Michael Jordan, Milorad Čavić, Usein Bolt and Novak Đoković. However, there was no statically significant difference according to gender $\left(\chi^{2}=125.025 ; d f=101 ; p<.053\right)$. For male athletes idols are Michael Jordan, Milorad Čavić and Roger Federer and for female athletes idols are Roger Federer, Novak Đokovic, Milorad Čavić and Usein Bolt.

It turns out that there is significant difference between male and female athletes according to gender of idol $\left(\chi^{2}=37.607 ; d f=1 ; p<.000\right)$. Both male and female athletes dominantly choose male athlete as their idol, but female athletes have larger percent of female idols. Actually, only four men choose female athlete as his idol. Senior female athletes select for their idols $87.4 \%$ male athletes and $12.6 \%$ female athletes.

There is also significant difference between athletes of different branches of sport according to gender of their idol $\left(\chi^{2}=42.829 ; d f=27 ; p<.027\right)$. Only handball players choose more female than male idols. Senior savate and jiu jitsu fighters choose none of female idols, so as athletics.

It turns out that the majority of athletes selected for their idol person that comes out of their sport $\left(\chi^{2}=2292.355 ; d f=702 ; p<.000\right)$. This was the case among soccer, water polo, basketball and handball players and also among athletics (track and field), gymnastics and wrestling. Exceptions were volleyball players who dominantly chose their idol among basketball players and tennis players. The same case was with dance, fencing and karate who chose their idol from tennis and jiu jitsu fighters chose their idol from swimming.

Idols of senior athletes mostly come from tennis, basketball and swimming, but there is also significant difference according to gender $\left(\chi^{2}=45.965 ; d f=26\right.$; $p<.009)$. Both gender chose their idol from tennis and basketball, but men more chose idols from basketball, swimming and soccer and women more chose idols from water polo. Women do not choose their idol in boxing and kick boxing and male don't choose their idol in handball and shooting, while they have similar attitude toward athletics and volleyball.

It turns out that senior athletes for their idol choose more often foreign athletes $-61.6 \%$ and in $38.4 \%$ domestic athletes. There was statistically significant difference between male and female respondents according to origin of chosen idol $\left(\chi^{2}=10.668 ; d f=1\right.$; $p<.001)$ and also between respondents from different branches of sports according to origin of chosen idol $\left(\chi^{2}=46.979 ; \mathrm{df}=27 ; p<.010\right)$. The highest percent of domestic athletes as their idols chose water polo and handball players, bocca, kick boxing and jiu jitsu fighters.

It turns out that senior athletes for their idol choose more often active athletes $-73.8 \%$ and in 26.2 percents of case retrieved athletes. There is no statistically significant difference between male and female respondents according to actuality of chosen idol. But, water polo, volleyball and basketball players and kyokushinkai fighters in larger percent then others choose their idol among retrieved athletes $\left(\chi^{2}=58.803\right.$; $d f=27 ; p<.000$ ).

Also, when it come to names, idol for water polo players was Vladimir Vujasinović, for handball players Andrea Lekić, for volleyball and basketball players Michael Jordan, for wrestlers Aleksandr Karelin and for jiu jitsu fighters the idol was Milorad Čavić $\left(\chi^{2}=3761.762 ; d f=2727 ; p<.000\right)$.

\section{DISCUSSION}

Senior athletes for their sports idols, in most cases elect Roger Federer, followed by Michael Jordan, Milorad Čavić, Usein Bolt and Novak Đoković. However, there was no statically significant difference according to gender. But, it is very significant data that there are three female athletes present on the list: Andrea Lekić, Jasna Šekarić and Jelena Janković and they were chosen only by female. So, including gender of athlete show some important data which would be lost if this distinction wasn't make. Also, very characteristic data is absence of Aleksandr Karelin and Vladimir Vujasinović at girl's sample. Reason for this might be a strong masculine message in water polo and wrestling, which symbolize high presence of physical strength and power and emphasize masculine body shape. Also, these sports are not very popular and numerous among girls in Serbia and there are no important results of domestic female athletes in these sports. In a study of young people in Germany by Biskup and Pfister (1999), girls and boys very rarely identified with sports women despite the high profile of Steffi Graf in the German sporting culture. Results of this research are consistent with theirs, but it is important to say that Andrea Lekić, Jasna Šekarić and Jelena Janković are domestic athletes and still active and they are among best ever in Serbia in their sports.

Both male and female athletes dominantly choose male athlete as their idol, but female athletes have larger percent of female idols. Senior athletes select for their idols $87.4 \%$ male athletes and $12.6 \%$ female athletes. Balswick and Ingoldsby (1982) surveyed 


\section{TABLE 2}

Sports from which sports idol coming from.

\begin{tabular}{ccclclc}
\hline \multirow{2}{*}{ Rank k } & \multicolumn{2}{c}{ Total } & \multicolumn{2}{c}{ Male } & \multicolumn{2}{c}{ Female } \\
\cline { 2 - 7 } & Sport of Idol & $\%$ & Sport of Idol & $\%$ & Sport of Idol & $\%$ \\
\hline 1 & tennis & 21.5 & tennis & 34.0 & tennis & 31.0 \\
\hline 2 & basketball & 17.9 & basketball & 31.0 & basketball & 23.0 \\
\hline 3 & swiming & 11.3 & swiming & 21.0 & swiming & 13.0 \\
\hline 4 & soccer & 9.6 & soccer & 18.0 & water polo & 13.0 \\
\hline 5 & athletics & 8.9 & athletics & 14.0 & athletics & 13.0 \\
\hline 6 & water polo & 7.0 & water polo & 8.0 & soccer & 11.0 \\
\hline 7 & volleyball & 4.0 & volleyball & 6.0 & handball & 7.0 \\
\hline 8 & handball & 2.3 & boxing & 6.0 & volleyball & 6.0 \\
\hline 9 & boxing & 2.0 & kick boxing & 5.0 & shooting & 5.0 \\
\hline
\end{tabular}

FIGURE 2

Rang lista of sportskih idola sportista seniora.

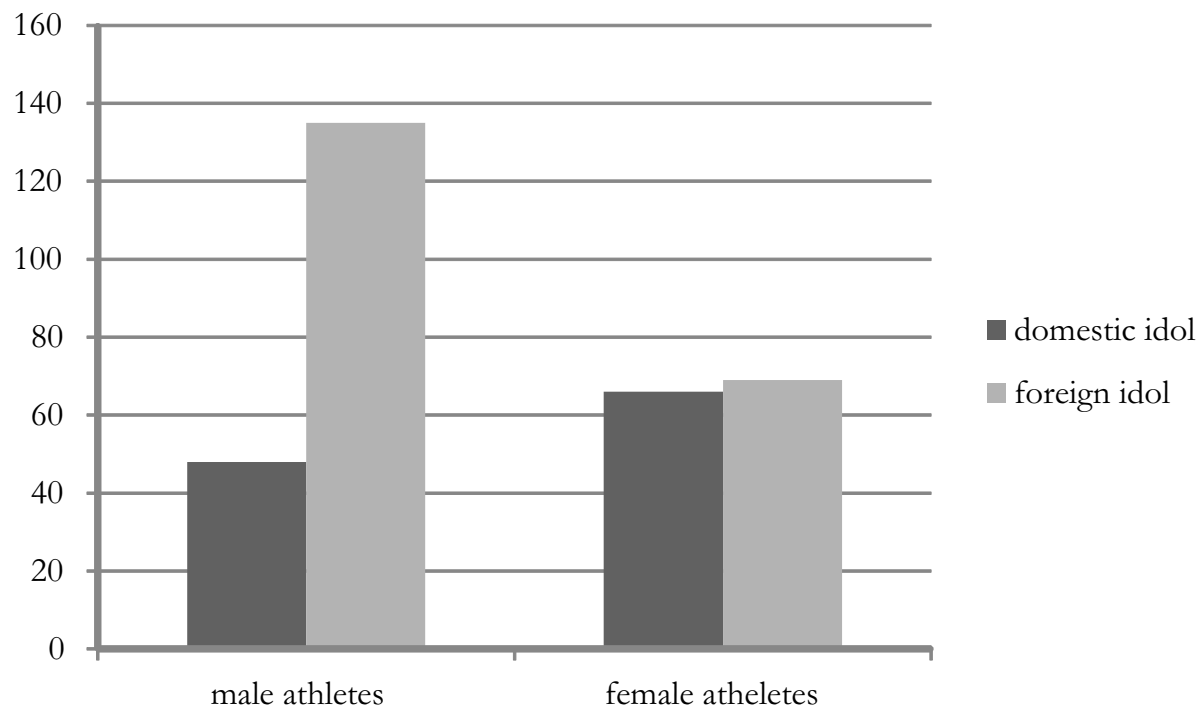

American adolescents and found that seven male heroes were selected for every one female heroine. Melnick and Jackson (2002) found that 78.4\% of chosen idols were males and $21.6 \%$ females. Crosstabulations revealed that $89.8 \%$ of the males chose a same-sex idol while just $10.2 \%$ 'crossed over' and chose a female. For females, six times as many (66.8\%) 'crossed-over' and chose a male public figure for their hero; just $33.2 \%$ chose a female. On the contrary, Teigen, Normann, Bjorkheim, and Helland (2000) found that the same sex idols were chosen by practically all the boys and by $83 \%$ of the girls. In sport area, while boys almost exclusively mentioned same sex models, about $30 \%$ of the girls selected a person of the opposite sex, with the hero from the Lillehammer Olympics, Koss, mentioned almost equally often by girls as by boys. There is also significant difference

between athletes of different branches of sport according to gender of their idol. Only handball players choose more female than male idols. Reason for this is the fact that Serbian male handball players are not as the top level as they used to be for many years, until Andrea Lekić is one of the best female handball players in the world in this moment. Senior savate and jiu jitsu fighters choose none of female idols, so as athletics.

It turns out that the majority of athletes selected for their idol person that comes out of their sport. This was the case among soccer, water polo, basketball and handball players and also among athletics (track and field), gymnastics and wrestling. Fleming, Hardman, Jones, and Sheridan (2005) also found that elite young British rugby league players dominantly choose idol from their sport. Exceptions were vol- 
leyball players who dominantly chose their idol among basketball players and tennis players. The same case was with dance, fencing and karate who chose their idol from tennis and jiu jitsu fighters chose their idol from swimming. The reason for this might be enormous success of domestic athletes in these sports and their media coverage in our country, which is much more then dance, fencing, karate and jiu jitsu. Also, when it come to names, idol for water polo players was Vladimir Vujasinović, for handball players Andrea Lekić, for volleyball and basketball players Michael Jordan, for wrestlers Aleksandr Karelin and for jiu jitsu fighters the idol was Milorad Čavić. Idols of senior athletes mostly come from tennis, basketball and swimming, but there is also significant difference according to gender. Both genders chose their idol from tennis and basketball, but men more chose idols from basketball, swimming and soccer and women more chose idols from water polo. Women do not choose their idol in boxing and kick boxing and male don't choose their idol in handball and shooting, while they have similar attitude toward athletics and volleyball.

It turns out that senior athletes for their idol choose more often foreign athletes $-61.6 \%$ and in $38.4 \%$ domestic athletes. Equal results found Melnick and Jackson (2002): domestic idol choose $36 \%$ of American and $34.2 \%$ of New Zealand sample. But, there was statistically significant difference between male and female respondents according to origin of chosen idol and also between respondents from different branches of sports according to origin of chosen idol. The highest percent of domestic athletes as their idols chose water polo and handball players, bocca, kick boxing and jiu jitsu fighters. Explanation for this is large amount of very successful athletes in Serbia in these sports for a very long time.

It turns out that senior athletes for their idol choose more often active athletes - $73.8 \%$ and in $26.2 \%$ retrieved athletes. These findings are not consisted with Teigen et al. (2000) who found that almost all idols were active. There is no statistically significant difference between male and female respondents according to actuallity of chosen idol. But, water polo, volleyball and basketball players and kyokushinkai fighters in larger percent then others choose their idol among retrieved athletes. So it seems that sports results have only contemporary value even among senior athletes, with large sport experience.

\section{CONCLUSION}

It seems that actuality of results and sports branch have the most significant role in process of choice of Serbian proffesional senior athletes sports idols, so as media coverage and international career and longer international sports experience in top level in process of adoption of behavior model and its contained intrinsic values. Senior athletes are more open toward values which promote foreign male athletes who are still active and coming from their sport, which emphasize their concentration on top results at international level as striving toward enhancing in their career. Female and domestic athletes, those whose career is ended and athletes who are competing in other sports are not in focus of senior athletes and their attention is not directed toward past time and legends, nor gender equality or promotion of national identity and values, but only toward reaching international competition and being the top on the world in their sport here and now.

\section{REFERENCES}

Balswick, J., \& Ingoldsby, B. (1982). Heroes and Heroines among American Adolescents. Sex Roles, 8, 243-249. doi: 10.1007/BF00287308

Biskup, C., \& Pfister, G. (1999). I Would Like to be Like her/him: Are Athletes »Role Models« for Boys and Girls'. European Physical Education Review, 5(3), 200-215. doi: 10.1177/ 1356336X990053003

Boorstin, D. J. (1961). The Image: A Guide to PseudoEvents in America. New York, NY: Harper \& Row, Publishers, Incorporated.

Bush, A. J., Martin C. A., \& Bush, V. D. (2004). Sports celebrity influence on the behavioral intentions of Generation Y. Journal of Advertising Research, 44, 108-118. doi: 10.1017/ S0021849904040206

Chung, H. (2003). Sports star v. rock star in globalizing popular culture. International Review for the Sociology of Sport, 38, 99-108. doi: $10.1177 / 1012690203038001731$

de Ruyter, D., \& Conroy, J. (2002). The Formation of Identity: The Importance of Ideals. Oxford Review of Education, 28(4), 509-522. doi: 10.1080/0305498022000013643

Dubner, S. J. (2003). Confessions of a hero-worshipper. New York, NY: William Morrow.

Erdogan, B. Z. (1999). Celebrity endorsement: A literature review. Journal of marketing management, 15 (4), 291 - 314. doi: 10.1362/ 026725799784870379

Erdogan, B. Z., Baker, M. J., \& Tagg, S. (2001). Selecting celebrity endorsers: The practitioner's perspective. Journal of Advertising Research, 41(3), 39-48. 
Fleming, S., Hardman, A., Jones, C., \& Sheridan, H. (2005). »Role models« among elite young male rugby league players in Britain. European Physical Education Review, 11(1), 51-70. doi: 10.1177/1356336X05049824

Harris, J. C. (1986). Athletic exemplars in context: General exemplar selection patterns in relation to sex, race, and age. Quest, 38, 95-115. doi: 10.1080/00336297.1986.10483845

Jones, M. J., \& Schumann, D. W. (2000). The Strategic Use of Celebrity Athlete Endorsers in Sports Illustrated: An Historic Perspective. Sport Marketing Quarterly, 9(2), 65-76.

Kamins, M. A., Brand, M. J., Hoeke, S. A., \& Moe, J. C. (1989). Two-sided versus one-sided celebrity endorsements: The impact on advertising effectiveness and credibility. Journal of Advertising, 18(2), 4-10. doi: 10.1080/ 00913367.1989 .10673146

Lines, G. (2001). Villains, fools or heroes? Sports stars as role models for young people. Leisure Studies, 20, 285-303. doi: 10.1080/0261436011 0094661

Jones, M. J., \& Schumann, D. W. (2000). The strategic use of celebrity athlete endorsers in Sports Illustrated: An historic perspective. Sport Marketing Quarterly, 9, 65-76.

Maddux, J. E., \& Rogers, R. W. (1980). Effects of source expertness, physical attractiveness, and supporting arguments on persuasion: A case of brains over beauty. Journal of Personality and Social Psychology, 39(2), 235-244. doi: 10.1037/0022-3514.39.2.235

Martin, J. H. (1996). Is the athlete's sport important when picking an athlete to endorse a nonsport product? Journal of Consumer Marketing, 13, 28-43. doi: 10.1108/07363769610152581

McCutcheon, L. E., Lange, R., \& Houran, J. (2002). Evidence for non-pathological and pathological dimensions of celebrity worship. British Journal of Psychology, 93, 67-87. doi: 10.1348/000712602162454; PMid: 11839102

McGuire, W. J. (1985). Attitudes and attitude change. In Aronson, G. La. E. (Ed.), Handbook of social psychology (pp. 233-346). New York: Random House.

Melnick, M. J., \& Jackson, S. J. (2002). Globalization american-style and reference idol selection: The Importance of Athlete Celebrity Others among New Zealand Youth. International Review For The Sociology Of Sport, 37(3-4), 429-448. doi: $10.1177 / 1012690202037004027$

Premeaux, S. R. (2005). The attitudes of middle class male and female consumers regarding the effectiveness of celebrity endorsers. Journal of Promotion Management, 11(4), 33-48. doi: 10.1300/J057v11n04_04

Raviv, A., Bar-Tal, D., Raviv, A., \& Ben-Horin, A. (1996). Adolescent idolization of pop singers: Causes, expressions, and reliance. Journal of Youth and Adolescence, 25, 631-650. doi: 10.1007/ BF01537358

Stevens, J. A., Lathrop, A. H., \& Bradish, C. L. (2003). Who is your hero? Implications for athletic endorsement strategies. Sport Marketing Quarterly, 12, 103-110.

Teigen, K. H., Normann, H. T. E., Bjorkheim, J. O., \& Helland, S. (2000). Who Would You Most Like to be Like? Adolescents' ideals at the beginning and the end of the century. Scandinavian Journal of Educational Research, 44(1), 5-26. doi: 10.1080/713696661

Wann, D. L., Melnick, M. J., Russell, G. W., \& Pease, D. G. (2001). Sport fans: The psychology and social impact of spectators. New York: Routledge Press.

Yue, X. D., \& Cheung, C. (2000). Selection of favourite idols and models among Chinese young people: A comparative study in Hong Kong and Nanjing. International Journal of Behavioral Development, 24, 91-98. doi: 10.1080/016502500383511

Received: Marta 11, 2013 Revision received: Jun 10, 2013 Accepted: Jun 29, 2013

Correspondence to: Jelena Ilić, $\mathrm{PhD}$

Kneza Višeslava 72 11070 Belgrade Serbia

Phone: 00381642285645

E-mail: ilicjelena@beotel.net 